\title{
Polycyclic Aromatic Hydrocarbons (PAHs) on size segregated particle phase in urban atmosphere, Istanbul
}

\author{
[Gülsüm SUMMAK ${ }^{1}$, Arslan SARAL ${ }^{1}$, S. Levent KUZU ${ }^{1}$, Hatice ÇOLTU ${ }^{1}$, Aigerim KISTAUBAYEVA ${ }^{1}$ ]
}

\begin{abstract}
Polycyclic aromatic hydrocarbons (PAHs) are semi-volatile organic compounds and present widely in ambient atmosphere. Due to the fact that PAHs are widely distributed in the environment and some species of them are carcinogenic, they are very important for human health and environment. High volume cascade impactor was used to collect the particulate matters according to particle size fractions between February 2013 and June 2014, in Istanbul. Particulate matters were collected according to size ranges $>7.2 \mu \mathrm{m}, 7.2-3 \mu \mathrm{m}, 3-1.5 \mu \mathrm{m}, 1.5-0.95 \mu \mathrm{m}$, $0.95-0.49 \mu \mathrm{m},<0.49 \mu \mathrm{m}$. 15 PAH species were analyzed in samples. Average of total PAH concentrations were found as $31.62 \mathrm{ng} / \mathrm{m}^{3}$. Total PAH size distribution was found between 0.95-1.5 $\mu \mathrm{m}$. All investigated ring PAH species showed single modal distribution in size range of 0.95-1.5 $\mu \mathrm{m} .4,5$ and 6-ring PAH species have high concentration in almost each size range. According to the obtained results, 4 , 5, 6-ring PAHs are abundant on the particles below $3 \mu \mathrm{m}$ when compared to 3-ring PAHs. Despite being abundant of 4, 5, 6-ring PAH types in each size range, 4 and 6-ring PAHs have less TEF values than 5-ring PAH types. Respirable carcinogenic PAH species were found in İstanbul urban area.
\end{abstract}

Keywords-PAHs, particle size distribution, $\mathbf{P M}_{2.5}$, TEF.

\section{Introduction}

In the past century, anthropogenic emissions which lead to formation of PM, have been dramatically increased and consequently resulted in adverse effects on health, visibility in urban and rural areas, acid deposition and the world's radiation balance [1],[2],[3],[4]. There can be diverse effects of PM on human health, the highest hazard given to health is through the respiratory system [5].

In order to understand the possible health effects of particulate matter, the size distribution information of the particulate matter is needed to be known [6]. This information is crucial because these pollutants contribute to the ecosystem and enter the human respiratory system [7],[8],[9]. Particle size distribution determines the air movement of the particles, their dry or wet deposition properties, atmospheric residence times and their deposition to the lungs [8],[10],[11],[12].

PAHs are emitted to the atmosphere from several natural and anthropogenic sources such as transportation, residential heating, wood burning, agricultural waste incineration, forest fires, land, sea and air vehicles, power plants, cigarette smoke, waste incineration plants, asphalt roads [13],[14],[15],[16].

Gülsüm SUMMAK

${ }^{1}$ Yildiz Technical University

Turkey
As PAHs are widespread in the environment and some species of them are carcinogenic, they are regarded as very important pollutants [8],[13]. Due to their carcinogenic and mutagenic properties PAHs are widely studied in the scientific community [17],[18]. The US EPA classified 16 of the PAHs as priority pollutants due to their high carcinogenic potential and mutagenic properties [19],[20],[21].

Risk assessment of human PAH exposure can be assessed by size distribution [7]. PAHs predominantly contribute to fine aerosols ( $\mathrm{Dp}<2 \mu \mathrm{m})$ [6],[17]. Fine particles can reach the pulmonary alveoli [6]. Larger particles are retained in the upper respiratory tract and is excreted in the sputum [7]. Deposition fluxes of PAHs in the human respiratory tract reveal the major contributors to the whole toxicity related to regions [22].

A number of studies related to size distribution of PAHs were made in the world. In these researches, particulate matters were collected by using sizesegregated impactors. Seasonal concentrations and distribution modals of particulate matters were evaluated [8],[22],[23],[24],[25],[26],[27],[28].

The aim of this study is to determine the size distribution of PAHs in a metropolitan city. Size distribution results of PAHs were evaluated according to ring number. The data presented here will also help to understand the potential health risk of PAHs on particular phase. A number of studies about PAHs have been conducted in Turkey but they are generally related to particle/gaseous phase and dry/wet deposition [29],[30],[31],[32]. Moreover, this research is the first PAH research depending on particle fraction in Turkey.

\section{Materials and Methods}

\section{A. Sampling Station}

Sampling area was chosen as Yildiz Technical University Davutpasa Campus. Campus is located next to Topkapi where the predecessor industrial area of Istanbul is. There are numerous of small and medium scale enterprises and they still continue processing although large-scale factories stopped their production activity. As seen in the figure below, there are intercity bus terminal to the north of the sampling location, residential area is intensely to the west and north, industrial area is to the east and south. 
Proc. of the Third Intl. Conf. on Advances in Bio-Informatics and Environmental Engineering - ICABEE 2015 Copyright (C) Institute of Research Engineers and Doctors, USA .All rights reserved.

ISBN: 978-1-63248-078-1 doi: 10.15224/ 978-1-63248-078-1-02

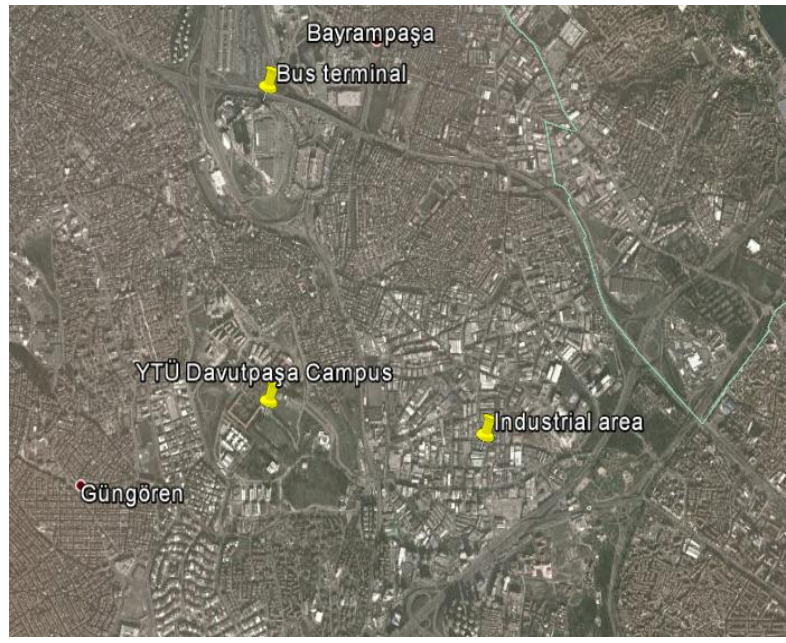

Figure 1. Sampling station location

\section{B. Sampling and Analysis}

High volume cascade impactor (Staplex brand) was used to collect the particulate matters according to their particle size fractions. The samples were collected between February 2013 and June 2014. Sampling were performed once a week through 38 weeks. Cascade impactor was operated at a flowrate of $1.1 \mathrm{~m}^{3} \mathrm{~min}^{-1} .30$ hours of sampling period is sufficient to be able to determine all targeted PAH type. The particles were collected in 6 sizes. 5 stages of the impactor enable the separation of the particles by inertial impaction mechanism, while the sixth stage uses the filtration mechanism to collect the particles. Cut diameter of the stages are $7.2 \mu \mathrm{m}, 3 \mu \mathrm{m}, 1.5 \mu \mathrm{m}, 0.95 \mu \mathrm{m}, 0.49 \mu \mathrm{m}$, $<0.49 \mu \mathrm{m}$, respectively. Totally 228 air samples were collected and analysed. Gravimetric measurements were done by AND GR-202 analytical microbalance. Glass fiber filter (GFF) was used to collect the particles. Before sampling process, GFFs were wrapped by an aluminum foil and heated at $450^{\circ} \mathrm{C}$ in a furnace for 6 hours to remove any organic residuals. Then, the filters were conditioned at $50 \pm 5 \%$ relative humidity and $20 \pm 2^{\circ} \mathrm{C}$ temperature.

Extraction and analysis of the samples were performed in accordance with the following methods. GFFs of the cascade impactor were placed in glass jars and were extracted with $50 \mathrm{ml} \mathrm{1:4}$ dichloromethane (DCM) / petroleum ether (PE), with the addition of $1 \mathrm{ml}$ surrogate standard in an ultrasonic bath for half an hour. After that, $50 \mathrm{ml}$ solvent mixture were added again and extraction was continued for another half an hour. Total extraction time was 1 hour. Surrogate standards were acenaphthene-d10, phenanthrene-d10, chrysene-d12, perylene-d12 of $4 \mathrm{ng} \mu \mathrm{l}^{-1}$. All samples were concentrated using a rotary evaporator and were reduced to $5 \mathrm{ml}$. After that, the solvent mixture was changed into hexane (HEX) with the addition of $15 \mathrm{ml}$ HEX and this step was repeated twice. The final solution was reduced to $2 \mathrm{ml}$ using a gentle pure nitrogen blow down system [14],[33],[34].

The next step is clean-up procedure. Samples were passed through alumina and silicic acid column and were separated into fractions. $3 \mathrm{~g}$ silicic acid (3\% water), $2 \mathrm{~g}$ neutral alumina ( $6 \%$ water) and $2 \mathrm{~g} \mathrm{Na}_{2} \mathrm{SO}_{4}$ were placed in to the column, respectively. Prior to the fractionation the columns were eluted with $20 \mathrm{ml} \mathrm{PE}$ and $20 \mathrm{ml}$ DCM. Then, the sample in $2 \mathrm{ml}$ HEX was poured to the column and PAHs were eluted with $20 \mathrm{ml}$ DCM. This solution contains the PAH fraction. The final extracts were exchanged into HEX and concentrated to $1 \mathrm{ml}$ under gentle nitrogen blow down system. At the final stage internal standard mixture of pyrene-d10 of $4 \mathrm{ng} / \mu \mathrm{l}$ were spiked for volume correction.

Quantification of PAH concentrations were determined by gas chromatograph (GC) Perkin Elmer Clarus 500 equipped with a Clarus 560S Mass Spectrometer (MS) detector. HP-5MS, $30 \mathrm{~m}$ x $0.25 \mathrm{~mm}$ x $0.25 \mu \mathrm{m}$, was used as a capillary column. The inlet temperature of the $\mathrm{GC}$ oven was $250^{\circ} \mathrm{C}$. The oven temperature program used in the $\mathrm{PAH}$ analysis was $50^{\circ} \mathrm{C}$ (1 $\mathrm{min}$ ), $25^{\circ} \mathrm{C} / \mathrm{min}$ to $200^{\circ} \mathrm{C}, 8^{0} \mathrm{C} / \mathrm{min}$ from 200 to $300^{\circ} \mathrm{C}$ and remain $5.5 \mathrm{~min}$ at $300^{\circ} \mathrm{C}$. The mass inlet line temperature was kept at $180^{\circ} \mathrm{C}$ and the source temperature at $200^{\circ} \mathrm{C}$. The carrier gas was ultra pure helium $(\mathrm{He})$ at $1.0 \mathrm{ml} / \mathrm{min}$ flow. Splitless injection was used. GC were performed in SIR (Selected Ion Recording) mode. Seven different level of standards were prepared ranging between 0.05 and $10 \mathrm{ng} / \mu \mathrm{l}$ for calibration procedure. After each 10 sample injections, stability was checked with the medium standard injection. The average determination coefficient value of the calibration curve $\left(\mathrm{r}^{2}\right)$ was 0.995 .

Acenaphthylene (Acy), acenaphthene(Ace), fluorene (Flu), phenanthrene (Phe), anthracene (Ant), fluoranthene (Flt), pyrene (Pyr), benz(a)anthracene (BaA), chrysene $(\mathrm{Chr})$, benzo(b)fluoranthene $(\mathrm{BbF})$, benzo(k)fluoranthene $(\mathrm{BkF})$, benzo(a)pyrene $(\mathrm{BaP})$, indeno(1,2,3-c,d)pyrene (IcdP), dibenz(a,h)anthracene (DahA) and benzo(g,h,i)perylene (BghiP) were analysed in GC-MS.

\section{Quality Assurance/Quality Control $(Q A / Q C)$}

All samples were spiked with surrogate standards to calculate the recovery efficiency prior to the extraction process. Achieved efficiency values were shown in Figure 2. Blue bars represent average recovery values of the surrogates and whiskers extending from the bars represent standard deviations.

Limit of detection (LOD) values were calculated for each specie as average blank concentrations plus three times of the standard deviations [33],[35]. Sample concentrations detected under the LOD value were ignored. Blank samples were collected for each set of analysis. All results were blank corrected. 
Proc. of the Third Intl. Conf. on Advances in Bio-Informatics and Environmental Engineering - ICABEE 2015 Copyright (C) Institute of Research Engineers and Doctors, USA .All rights reserved.

ISBN: 978-1-63248-078-1 doi: 10.15224/ 978-1-63248-078-1-02

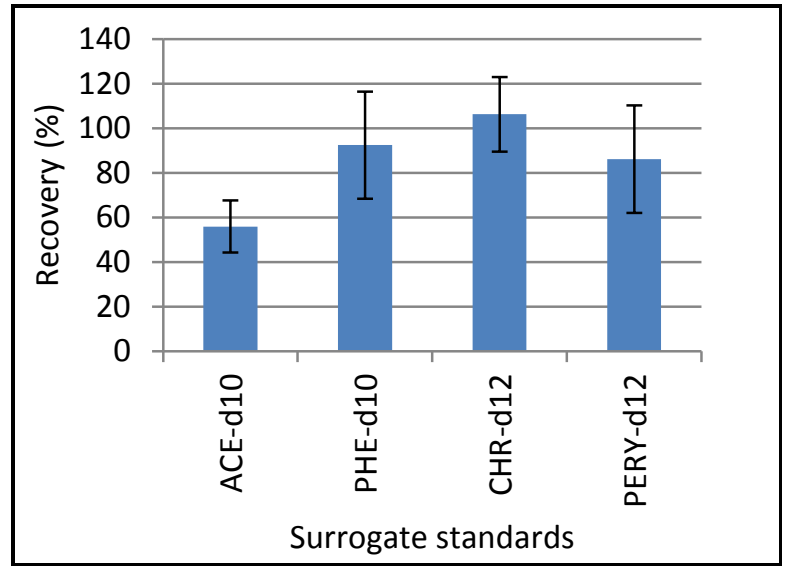

Figure 2. Surrogate standards recovery percentages

\section{Results and Discussions}

PAHs are found in both fine and coarse particle size ranges. PAHs which comprise of such as combustion sources are usually formed in fine particle size, then grow and can become coarse particles or low molecular weight PAHs can evaporate from fine particles, then condensate on the coarse particles and so they may be present in coarse particles [13].

Using the achieved data for each impactor stage, particle size distributions and PAHs are plotted on a $\mathrm{dC} / \mathrm{d} \log \mathrm{Dp}$ vs $\log \mathrm{Dp}$ graph. The results are shown in Figure 3 and Figure 4.

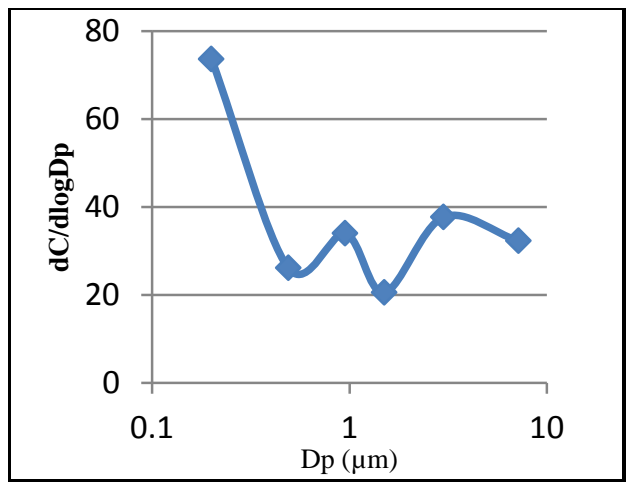

Figure 3. Particle size distributions of particulate matter

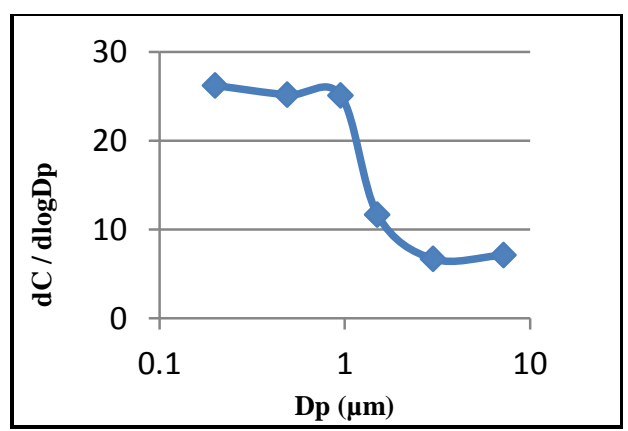

Figure 4. Particle size distributions of $\Sigma$ PAHS

Different size distribution modes were present for particles and PAHs. Ambient particles likely have 3 modes. The first mode has cut-off diameter of $3 \mu \mathrm{m}$. This fraction represents wind blown dusts. The second mode has $0.95 \mu \mathrm{m}$ cut-off diameter. This fraction is corresponding to accumulation mode particles. At last, third peak occurs $<0.49 \mu \mathrm{m}$. However, a clear peak is not present due to last stage cut-off value of the impactor. On the other hand, PAHs have one dominant peak at 0.95 $\mu \mathrm{m}$. Carbon content of the aerosol sizes affects the partitioning of semi volatile organic compounds between gas and particle phases [36]. In urban areas fine particles are mostly consist of organic carbon [37]. Hence, PAHs in fine particles seem to be more dominant in this study.

Two different representation were prepared considering particulate matter masses and PAH masses. In Figure 5, ratio of PAH masses relative to particulate masses for each stage was given. It is seen that particles having mass median diameter of $0.49 \mu \mathrm{m}$ have the highest PAH enrichment which gives an idea that the corresponding stage is dominated by accumulation mode PAHs. Possible source seems to be combustion but the source and the receptor (sampling point) have enough distance to grow a PAH containing nuclei mode into accumulation mode. In figure 5, it can come to mind why $<0.49 \mu \mathrm{m}$ (back-up filter) stage does not have high ratios if finer fractions have high concentrations of PAHs. The reason of this low mass ratios is higher mass collection in $<0.49 \mu \mathrm{m}$ stage. The other stage collects the particles by impaction mechanism while the last stage collects filtration mechanism. The particulate matter concentrations of other stages are in the range 2.8-36.2 $\mu \mathrm{g} / \mathrm{m}^{3}$ while the back-up concentrations are in $12.4-54.2$ $\mu \mathrm{g} / \mathrm{m}^{3}$. Higher mass concentrations lead to lower mass ratios in figure.

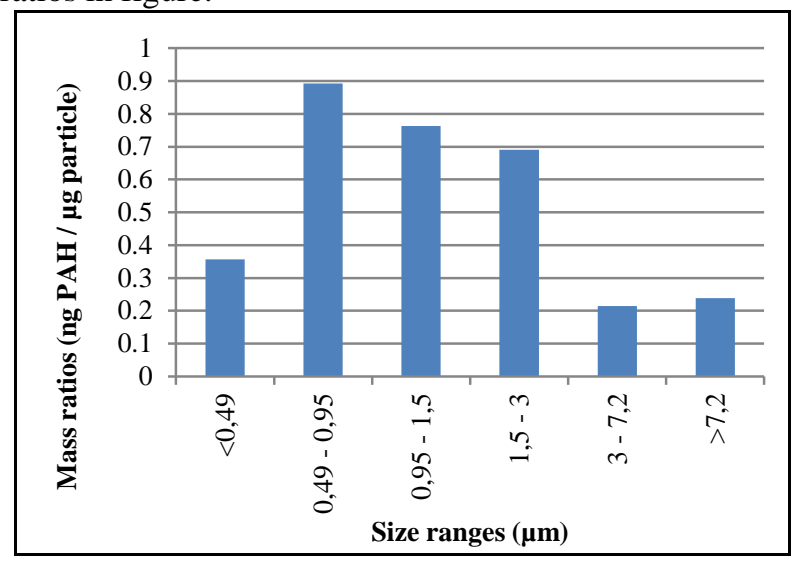

Figure 5.PAH mass ratios

In Figure 6, PAH concentrations ratios related to stage concentrations were shown. Particles under 0.49 $\mu \mathrm{m}$ size have the highest concentrations in all of the stage concentrations and these ratios are gradually decreasing from this diameter until particle diameter $7.2 \mu \mathrm{m}$. After $7.2 \mu \mathrm{m}$ diameter a small amount of increase was shown. The reason may be the upper cutting diameter for this stage which is not certain and lots of particles $(>7.2 \mu \mathrm{m})$ have larger size ranges than other stages and this may cause an increase. Both Figure 4 and 5 reveal that particular PAHs are dominated in fine fractions and the same size range ( $0.49-0.95 \mu \mathrm{m})$ are seen the highest from the two figures. 
Proc. of the Third Intl. Conf. on Advances in Bio-Informatics and Environmental Engineering - ICABEE 2015 Copyright (C) Institute of Research Engineers and Doctors, USA .All rights reserved.

ISBN: 978-1-63248-078-1 doi: 10.15224/ 978-1-63248-078-1-02

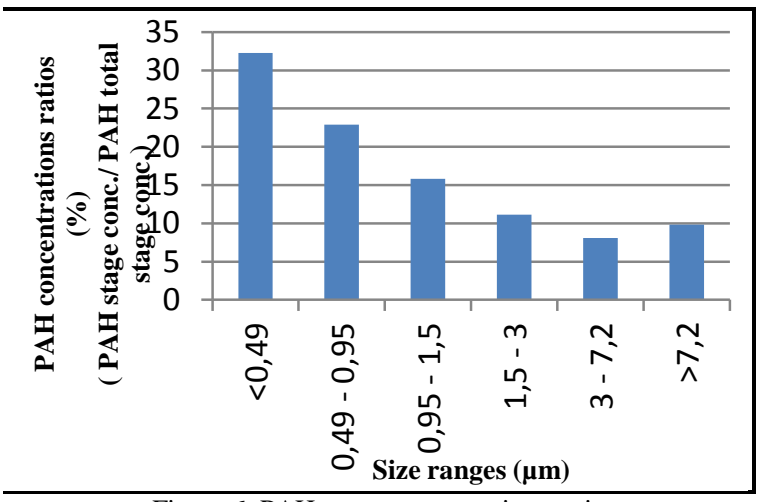

Figure 6. PAH stage concentrations ratio

Atmospheric PAHs tend to partition between gas and particle phases. In a study, carcinogenic 5-6 rings PAH species are reported to be dominant particularly in the

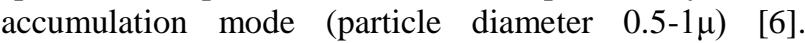
Particle size distributions of the particles depend on formation processes, sources, atmospheric conditions and a number of physical features of particles. Particle size distribution of PAHs depending on their ring numbers were given in Figure 7.

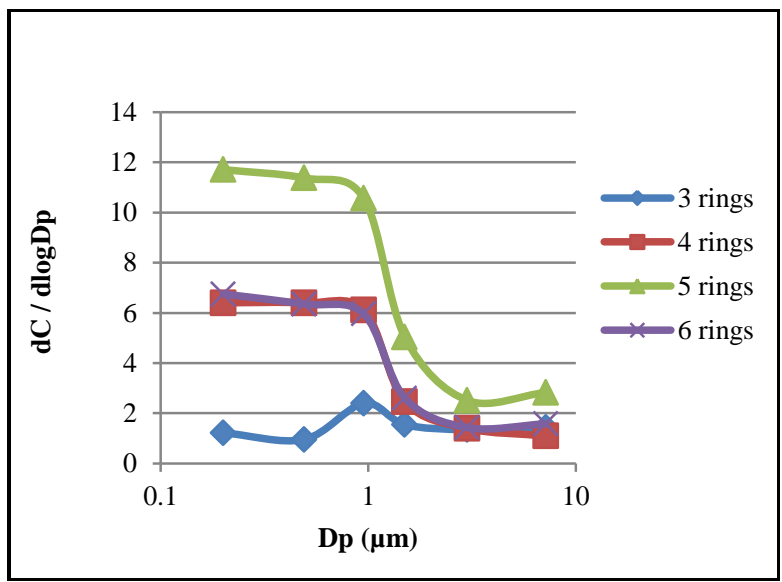

Figure 7. Size distributions relative to ring numbers

3, 4, 5, 6-ring PAH species exhibit a single mode distribution at $0.95-1.5 \mu \mathrm{m}$ range. Finer fractionations could help this peak clearly but the cascade impactor which we used didn't allow that happen. Zhou et al., (2005) reported that, 2 and 3-ring PAHs showed bimodal distribution, 4-ring PAH species showed unimodal distribution in their study [38]. In the same study, 5-6 ring $\mathrm{PAH}$ species again showed unimodal distribution. Current results are similar to the data in their study for 4, 5, 6-ring PAH species. Chrysikou et al. (2009) found that size distribution of all PAHs species were in single mode for $0.95-1.5 \mu \mathrm{m}$ size range in Greece [8]. In this study, results were found to be in line with the results in Greece for total PAH size distribution. In both studies, singlemode distribution were found at $0.95 \mu \mathrm{m}$.

In Figure 8, low molecular weight of 3-ring PAHs generally have high concentration levels at both coarse and fine particle size range. 3-ring $\mathrm{PAH}$ species emerge from nucleus mode, then they may be adsorbed onto coarse particles due to their volatility [13]. High concentrations of 3-ring PAH's at coarse mode can be explained by this situation. In Figure 8; 4, 5 and 6-ring
PAH species show similar increasing tendency towards to smaller particle sizes. 5-ring PAH species have the highest concentrations in every size ranges. 4 and 6-ring PAH species concentrations are nearly close to each other in every size ranges. 5-6 ring $\mathrm{PAH}$ species tend to remain in fine fraction due to high molecular weight and low volatility [9],[13]. Mostly, particle diameters below 2 $\mu \mathrm{m}$ and 5-6 ring PAHs are carcinogenic [8],[9]. In the acquired data, it is observed that, there is an increase in 5 and 6 ring PAHs from $3 \mu \mathrm{m}$ towards the smallest particle diameter.

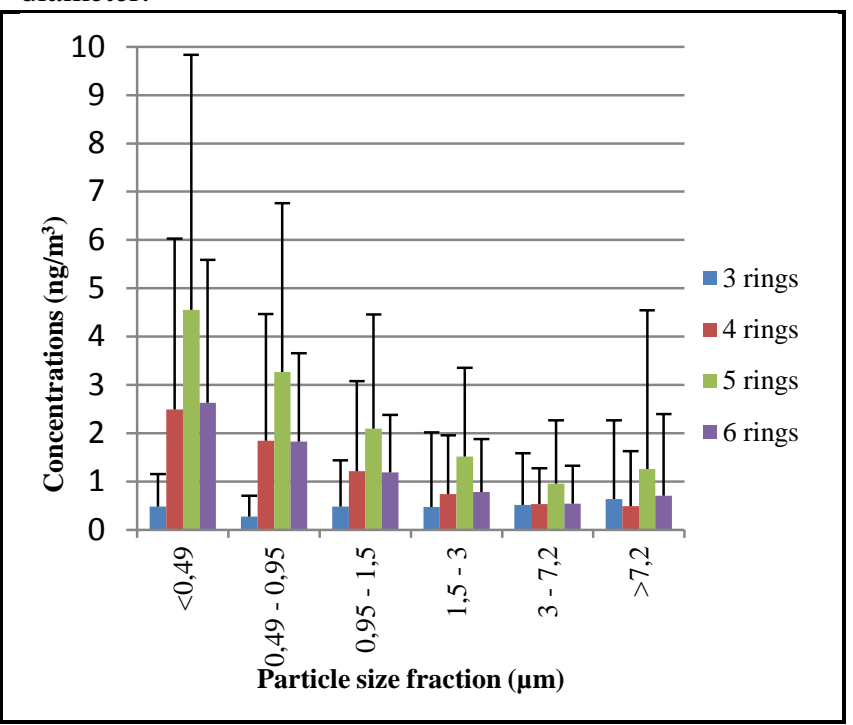

Figure 8 . PAH concentrations relative to ring numbers

Also, it is important to say that $\mathrm{BaP}$ average concentration is $3,24 \mathrm{ng} / \mathrm{m}^{3}$. This value is higher than desired target value $\left(1 \mathrm{ng} / \mathrm{m}^{3}\right)$ in Air Quality Assessment and Management Regulation (AQAMR) in Turkey [39].

5 and 6-ring PAH species concentrations except DbA were higher concentrations than other PAH species in Table 1. While Acy, Flu, Pyr, BkF, dibenz[a,h]anthracene, indeno [1,2,3-cd] pyrene are reported to be indicator of traffic emissions, BgHip are reported to be in the presence of gasoline and diesel combustion [40],[41]. Also, dibenz[a,h]anthracene is generated through LPG combustion processes [41]. Fluoranthene and pyrene are always indicators of coal burning [15]. General observation for 5-6 ring $\mathrm{PAH}$ species shows that they are originated from traffic emissions.

Industrial sites located in the Davutpaşa region are: the automotive industry, metallurgical industry, textile, machinery, packaging, washing knitwear, socks textile, metal coatings industry. 3-ring PAHs could be released from the surrounding industries. Automotive, textile, metal coatings can cause these emissions. 5-6 ring PAHs are generally reported to be traffic emissions. Sampling station is close to the central coach station of Istanbul. These sources are said to be the main emission sources for PAH species. 
Proc. of the Third Intl. Conf. on Advances in Bio-Informatics and Environmental Engineering - ICABEE 2015 Copyright (C) Institute of Research Engineers and Doctors, USA .All rights reserved.

ISBN: 978-1-63248-078-1 doi: 10.15224/ 978-1-63248-078-1-02

Table 1. Similar studies and comparison

\begin{tabular}{|c|c|c|c|c|c|c|c|c|c|c|c|c|c|}
\hline \multirow{2}{*}{$\begin{array}{c}\text { PAH } \\
\text { specie } \\
\text { s }\end{array}$} & \multicolumn{2}{|c|}{$\begin{array}{c}\text { Chrysikou et } \\
\text { al., 2009 } \\
\text { Urban, Greece } \\
\mathrm{ng} / \mathrm{m}^{3} \\
>7.5 \mu \mathrm{m}-< \\
0.95 \mu \mathrm{m} \\
5 \mathrm{stage}\end{array}$} & \multicolumn{2}{|c|}{$\begin{array}{c}\text { Amador- } \\
\text { Munoz et al., } \\
2010 \\
\text { Urban, Mexico } \\
<7.2 \mu \mathrm{m}-> \\
0.49 \mu \mathrm{m} \\
5 \mathrm{stage} \\
\mathrm{ng} / \mathrm{m}^{3}\end{array}$} & \begin{tabular}{|c} 
Schnelle \\
et al., \\
1995 \\
Urban \\
German \\
$\mathrm{y}$ \\
$\mathrm{ng} / \mathrm{m}^{3}$
\end{tabular} & \begin{tabular}{c|} 
Lim et \\
al., \\
2005 \\
Urban, \\
Austral \\
ia \\
$\mathrm{ng} / \mathrm{m}^{3}$
\end{tabular} & \multicolumn{2}{|c|}{$\begin{array}{l}\text { Akyüz and } \\
\text { Çabuk, 2008, } \\
\text { Turkey } \\
\text { PM } 2.5 \\
\mathrm{ng} / \mathrm{m}^{3}\end{array}$} & \multicolumn{3}{|c|}{$\begin{array}{c}\text { Hanedar et al., } 2011 \\
\text { Turkey } \\
\text { Sept. } 2006 \text { - Nov. } 2007 \\
\text { TSP + gas phase } \\
\mathrm{ng} / \mathrm{m}^{3}\end{array}$} & \multirow{2}{*}{\begin{tabular}{|c|} 
Oliveira \\
, et al., \\
2011 \\
Portugal \\
$10 \mu \mathrm{m}-$ \\
$<0.49$ \\
$\mu \mathrm{m}$ \\
4 stage \\
\\
\\
\\
Heavy \\
traffic \\
tunnel
\end{tabular}} & \multirow{2}{*}{\begin{tabular}{|c|c} 
This \\
study \\
$\mathrm{ng} / \mathrm{m} 3$ \\
$>7.2 \mu \mathrm{m}$ \\
$<0.49$ \\
$\mu \mathrm{m}$ \\
$6 \mathrm{stage}$ \\
\\
\\
\\
Feb. \\
$2013-$ \\
June \\
2014 \\
$\mathrm{n}=38$
\end{tabular}} \\
\hline & $\begin{array}{c}\text { Winter } \\
n=7\end{array}$ & $\begin{array}{c}\text { Summ } \\
\text { er } \\
n=7\end{array}$ & $\begin{array}{c}\mathrm{n}=18 \\
\text { Dry } \\
\text { season }\end{array}$ & $\begin{array}{c}n=24 \\
\text { Rainy } \\
\text { seaso } \\
n\end{array}$ & $\begin{array}{c}<0.49 \\
\mu m \\
6 \text { stage } \\
n=4 \\
\text { Novemb } \\
\text { er }\end{array}$ & $\begin{array}{c}\text { TSP + } \\
\text { gas } \\
\text { phase } \\
\mathrm{n}=26\end{array}$ & $\begin{array}{c}\text { Winter } \\
\text { Sept.- } \\
\text { May }\end{array}$ & $\begin{array}{l}\text { Summ } \\
\text { er } \\
\text { May- } \\
\text { Sept. }\end{array}$ & $\begin{array}{c}\text { Urban } \\
1\end{array}$ & $\begin{array}{c}\text { Urban } \\
2\end{array}$ & $\begin{array}{l}\text { Sub } \\
\text { urban }\end{array}$ & & \\
\hline NAP & - & 0,73 & - & 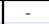 & - & - & - & - & 34,7 & 22,9 & 6,1 & 0,84 & \\
\hline $\mathrm{ACP}$ & 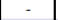 & & - & - & - & - & 0,7 & 0,1 & & & & & 18 \\
\hline ACT & 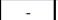 & & - & - & - & & - & & 13,7 & 8,3 & 2,1 & 13 & 0,16 \\
\hline FLN & - & 0,21 & - & - & - & 0,16 & - & - & 4,2 & 6 & 0,9 & 90 & 0,44 \\
\hline PHE & 0,75 & 0 , & & 0,145 & & & 78 & 03 & 0,2 & & & & \\
\hline ANT & 1,25 & 0,3 & 7 & 0,073 & 0,286 & 0,24 & 2,7 & 0,3 & 5,2 & 7,9 & 2,5 & 2,60 & 46 \\
\hline FL & 2,65 & 0,55 & 0,645 & 0,196 & 07 & & & 0,4 & 7 & 7,9 & 2,9 & & \\
\hline PY & 2,7 & 0,3 & 0,836 & 0,237 & & 0,3 & & & 4,7 & & & & \\
\hline $\mathrm{BaA}$ & 2,47 & 0,3 & 0,52 & 0,135 & 0,455 & 0,22 & 4,8 & 0.5 & 4 & 1,7 & 0,7 & 86 & 1,97 \\
\hline CHR & 3,73 & 0,92 & - & & 0,71 & 0,3 & 18,7 & 0,6 & ,7 & 2,5 & 1,1 & 1,56 & 2,50 \\
\hline $\mathrm{BbF}$ & 1,54 & 0,65 & 1,58 & 0,683 & 0,86 & 0,33 & 16 & 0,4 & 1,2 & 1,4 & 0,7 & 20,32 & 4,54 \\
\hline BkF & 0,83 & 0,6 & - & - & 0,46 & . & 9,2 & 0,2 & 0,4 & 0,5 & 0,3 & 3,10 & 4,22 \\
\hline $\mathrm{BaP}$ & 1,06 & 0,12 & 0,775 & 0,31 & 0,29 & 0,19 & 15,7 & 0,4 & 1,1 & 1,3 & 0,6 & 7,68 & 3,24 \\
\hline IcdP & 1,5 & 0,57 & 1,8 & 0,873 & 32 & 0,24 & 13,6 & 1,1 & 0,8 & 1,3 & 0,3 & 2,73 & 3,67 \\
\hline DbA & - & 0,4 & 0,183 & 0,108 & 0,075 & 0,56 & 1,1 & 0,1 & 0,5 & 0,7 & 0,4 & 0,13 & 1,7 \\
\hline Bghip & 1,81 & 0,5 & & & 0,77 & & & & & & & & \\
\hline$\Sigma$ & 20,35 & 6,55 & 9,80 & 4,26 & 6,35 & 3,90 & 152,70 & 5,70 & 100,7 & 84,6 & 25,1 & 139,38 & 31,62 \\
\hline
\end{tabular}

\section{A. Calculation of Toxicity Potential of PAHs}

PAHs are highly carcinogenic potential group of compounds. Each compound in this group have a different carcinogenic potential. In this study, carcinogenic potentials of PAHs in each size range depends on the size distribution of particulate matters were calculated by multiplying atmospheric $\mathrm{PAH}$ concentrations and Toxic Equivalent Factor (TEF) [44] and were given in Table 2 as benzo[a]pyrene equivalent concentrations (BaPE).

Table 2. BaP equivalent concentrations related to particle cut diameter

\begin{tabular}{|c|c|c|c|c|c|c|}
\hline \multirow{2}{*}{$\begin{array}{l}\text { PAH } \\
\text { specie } \\
\text { s }\end{array}$} & \multicolumn{6}{|c|}{ BaP equivalent concentrations $\left(\mathrm{ng} / \mathrm{m}^{3}\right)$} \\
\hline & $7,2 \mu \mathrm{m}$ & $\begin{array}{c}3 \\
\mu \mathrm{m} \\
\end{array}$ & $1,5 \mu \mathrm{m}$ & $\begin{array}{c}0,95 \\
\mu \mathrm{m}\end{array}$ & $\begin{array}{c}0,49 \\
\mu \mathrm{m}\end{array}$ & $0,2 \mu \mathrm{m}$ \\
\hline ACE & 0,0000 & 0,0000 & 0,0001 & 0,0000 & 0,0000 & 0,0000 \\
\hline FL & 0,0001 & 0,0001 & 0,0001 & 0,0001 & 0,0000 & 0,0001 \\
\hline PHE & 0,0001 & 0,0001 & 0,0001 & 0,0001 & 0,0001 & 0,0002 \\
\hline ANT & 0,0007 & 0,0013 & 0,0005 & 0,0011 & 0,0003 & 0,0008 \\
\hline FLT & 0,0001 & 0,0001 & 0,0001 & 0,0002 & 0,0003 & 0,0005 \\
\hline PYR & 0,0001 & 0,0002 & 0,0001 & 0,0003 & 0,0003 & 0,0005 \\
\hline $\mathbf{B a A}$ & 0,0171 & 0,0123 & 0,0234 & 0,0325 & 0,0489 & 0,0628 \\
\hline CHR & 0,0013 & 0,0013 & 0,0022 & 0,0038 & 0,0069 & 0,0094 \\
\hline $\mathbf{B b F}$ & 0,0403 & 0,0294 & 0,0439 & 0,0649 & 0,1023 & 0,1736 \\
\hline BkF & 0,0355 & 0,0286 & 0,0412 & 0,0631 & 0,1046 & 0,1491 \\
\hline BaP & 0,2767 & 0,1940 & 0,3213 & 0,5326 & 0,8762 & 1,0345 \\
\hline IcdP & 0,0327 & 0,0264 & 0,0372 & 0,0576 & 0,0911 & 0,1214 \\
\hline DbA & 0,2564 & 0,1816 & 0,3432 & 0,2835 & 0,3246 & 0,3386 \\
\hline BghiP & 0,0039 & 0,0028 & 0,0041 & 0,0061 & 0,0092 & 0,0141 \\
\hline Total & 0,6649 & 0,4781 & 0,8175 & 1,0461 & 1,5649 & 1,9056 \\
\hline
\end{tabular}

When Table 2 was examined, it was seen that the total of $\mathrm{BaP}$ equivalent concentrations in all size fractions ranges from 0.6649 to $1,906 \mathrm{ng} / \mathrm{m}^{3}$. The highest two concentrations of PAHs in each size range have been determined as $\mathrm{BaP}$ and $\mathrm{DbA}$. Also, percent values of $\mathrm{PAH}$ species in all sizes were calculated for easy evaluation of the data. These values ranged from $39.3 \%$ $(1.5 \mu \mathrm{m})$ to $55.99 \%(0,49 \mu \mathrm{m})$ for $\mathrm{BaP}$ when these valuse changed between $41.99 \%(1,5 \mu \mathrm{m})$ and $17.76 \%$ $(0,2 \mu \mathrm{m})$ for $\mathrm{DbA}$. The remaining percentages were distributed among the other types of PAHs in values between 0.01 and 9.11\%. Although $\mathrm{DbA}$ average concentrations are lower other than 5-ring PAH species (Table 1), its relative contribution to the carcinogenic potential is stronger due to its high TEF.

In another study in Istanbul, $\mathrm{BaP}$ equivalent concentrations were found as $1.14-3.68 \mathrm{ng} / \mathrm{m}^{3}$ in total suspended particulate matter (TSP) and gas phase. At the same study, the highest two concentrations of $\mathrm{BaP}$ equivalent concentrations have been determined as $\mathrm{BaP}$ and $\mathrm{DbA}$ [30]. The same species were highest concentrations in our study, too.

In a study in Konya from Turkey, BaP equivalent (BaPE) concentrations have been determined as 2.019 $\mathrm{ng} / \mathrm{m}^{3}$ ve $13 \mathrm{ng} / \mathrm{m}^{3}$ for different areas [32]. BaPE concentrations were found as the following in different countries; in the range of $0.1-2.63 \mathrm{ng} / \mathrm{m}^{3}$ in Italy by Lodovici and his friends (2003) [45], $0.711 \mathrm{ng} / \mathrm{m}^{3}$ in Spain by Vera Castellano and his friends (2003) [46], $4,11 \mathrm{ng} / \mathrm{m}^{3}$ in indoor air study which was used cascade impactor by Zhang et. al., (2012) [12], in the range of 0.14-3.59 $\mathrm{ng} / \mathrm{m}^{3}$ in China by Zhao et al., (2011) [27]. Various BaPE concentrations have been determined depending on countries. Different values are due to not only the different geography but also using alternative particle collection methods.

\section{Conclusion}

In previous studies in Turkey, PAH concentrations were found in particulate or gas phase. In this study, the concentrations of PAHs in particulate matter collected in a specific size range were investigated. Average particle size of all PAH species ranges between 0.95-1.5 $\mu \mathrm{m}$. This range is important since it is respirable particulate matter size range. PAH species in similar features were grouped according to the number of rings. All researched ring PAHs show mono modal distribution in size range of 0.95-1.5 $\mu \mathrm{m} .4,5$ and 6-ring $\mathrm{PAH}$ species have high concentrations almost in every size range. Especially high molecular weight PAHs are generally related to particulate matter and therefore it can threaten human health by inhalation. Particle diameters which are lower than 2 micrometers and are 5-6 ring of PAHs; are carcinogenic. It was observed that when particle size decreases, 5-6 ring PAHs concentrations increase. Toxicity equivalency factors of PAHs were calculated and the highest values were obtained for $\mathrm{BaP}$ and $\mathrm{DbA}$. In spite of being lower concentrations is ambient air, it is remarkable for DbA having high TEF values. BaP average concentration was found higher than target value in AQAMR in Turkey. Inhalation of particulate matters containing toxic organic components threat to human health. Researches on PAH concentrations of respirable particles are very important in terms of understanding the effects on human health. 


\section{Acknowledgment}

This research was supported by the Scientific and Technological Research Council of Turkey (TUBITAK) Project (Project no: 113Y538).

\section{References}

[1] T. Kindap, A. Unal, S.-H. Chen, Y. Hu, M. Odman, and M. Karaca, "Long-range aerosol transport from Europe to Istanbul, Turkey," Atmospheric Environment, vol. 40, pp. 3536-3547, 2006.

[2] J. Seinfeld and S. Pandis, "Atmospheric chemistry and physics: from air pollution to climate change," 2006.

[3] M. Koçak, N. Mihalopoulos, and N. Kubilay, "Origin and source regions of PM 10 in the Eastern Mediterranean atmosphere," Atmospheric Research, vol. 92, pp. 464-474, 2009.

[4] G. Borucu, H. Ozdemir, G. Demir, S. Yigit, and H. K. Ozcan, "Quantification of Atmospheric Particle Number Concentration for Selected Children Playgrounds: A Case Study in Istanbul," Journal of Residuals Science \& Technology, vol. 7, pp. 147-152, 2010.

[5] R. Hetland, F. Cassee, M. Refsnes, P. Schwarze, M. Låg, A. Boere, and E. Dybing, "Release of inflammatory cytokines, cell toxicity and apoptosis in epithelial lung cells after exposure to ambient air particles of different size fractions," Toxicology in Vitro, vol. 18, pp. 203-212, 2004.

[6] Y. Kawanaka, Y. Tsuchiya, S.-J. Yun, and K. Sakamoto, "Size distributions of polycyclic aromatic hydrocarbons in the atmosphere and estimation of the contribution of ultrafine particles to their lung deposition," Environmental science \& technology, vol. 43, pp. 6851-6856, 2009.

[7] S. Wu, S. Tao, and W. Liu, "Particle size distributions of polycyclic aromatic hydrocarbons in rural and urban atmosphere of Tianjin, China," Chemosphere, vol. 62, pp. 357-367, 2006.

[8] L. P. Chrysikou and C. A. Samara, "Seasonal variation of the size distribution of urban particulate matter and associated organic pollutants in the ambient air," Atmospheric Environment, vol. 43, pp. 4557-4569, 2009.

[9] Y. Zhu, L. Yang, Q. Yuan, C. Yan, C. Dong, C. Meng, X. Sui, L. Yao, F. Yang, and Y. Lu, "Airborne particulate polycyclic aromatic hydrocarbon (PAH) pollution in a background site in the North China Plain: concentration, size distribution, toxicity and sources," Science of The Total Environment, vol. 466, pp. 357-368, 2014.

[10] H. Kaupp and M. Mclachlan, "Atmospheric particle size distributions of polychlorinated dibenzo-p-dioxins and dibenzofurans (PCDD/Fs) and polycyclic aromatic hydrocarbons (PAHs) and their implications for wet and dry deposition," Atmospheric environment, vol. 33, pp. 85-95, 1999.

[11] A. Papageorgoulou, E. Manoli, E. Touloumi, and C. Samara, "Polycyclic aromatic hydrocarbons in the ambient air of Greek towns in relation to other atmospheric pollutants," Chemosphere, vol. 39, pp. 2183-2199, 1999.

[12] K. Zhang, B.-Z. Zhang, S.-M. Li, C. S. Wong, and E. Y. Zeng, "Calculated respiratory exposure to indoor sizefractioned polycyclic aromatic hydrocarbons in an urban environment," Science of the Total Environment, vol. 431, pp. 245-251, 2012.

[13] T. T. Hien, T. Kameda, N. Takenaka, and H. Bandow, "Distribution characteristics of polycyclic aromatic hydrocarbons with particle size in urban aerosols at the roadside in Ho Chi Minh City, Vietnam," Atmospheric Environment, vol. 41, pp. 1575-1586, 2007.

[14] Y. Tasdemir and F. Esen, "Urban air PAHs: concentrations, temporal changes and gas/particle partitioning at a traffic site in Turkey," Atmospheric Research, vol. 84, pp. 1-12, 2007.

[15] W.-L. Ma, Y.-F. Li, H. Qi, D.-Z. Sun, L.-Y. Liu, and D.-G. Wang, "Seasonal variations of sources of polycyclic aromatic hydrocarbons (PAHs) to a northeastern urban city, China," Chemosphere, vol. 79, pp. 441-447, 2010.
A. Birgül, Y. Tasdemir, and S. S. Cindoruk, "Atmospheric wet and dry deposition of polycyclic aromatic hydrocarbons (PAHs) determined using a modified sampler," Atmospheric Research, vol. 101, pp. 341-353, 2011.

[17] J. Duan, X. Bi, J. Tan, G. Sheng, and J. Fu, "The differences of the size distribution of polycyclic aromatic hydrocarbons (PAHs) between urban and rural sites of Guangzhou, China," Atmospheric Research, vol. 78, pp. 190-203, 2005.

[18] X. Bi, B. R. Simoneit, G. Sheng, S. Ma, and J. Fu, "Composition and major sources of organic compounds in urban aerosols," Atmospheric Research, vol. 88, pp. 256$265,2008$.

[19] G. Liu, G. Zhang, J. Li, X. Li, X. Peng, and S. Qi, "Spatial distribution and seasonal variations of polycyclic aromatic hydrocarbons (PAHs) using semi-permeable membrane devices (SPMD) and pine needles in the Pearl River Delta, South China," Atmospheric Environment, vol. 40, pp. 31343143, 2006.

[20] H. K. Bojes and P. G. Pope, "Characterization of EPA's 16 priority pollutant polycyclic aromatic hydrocarbons (PAHs) in tank bottom solids and associated contaminated soils at oil exploration and production sites in Texas," Regulatory Toxicology and Pharmacology, vol. 47, pp. 288-295, 2007.

[21] N. Sánchez, A. Callejas, A. Millera, R. Bilbao, and M. Alzueta, "Formation of PAH and soot during acetylene pyrolysis at different gas residence times and reaction temperatures," Energy, vol. 43, pp. 30-36, 2012.

[22] Y. Kameda, J. Shirai, T. Komai, J. Nakanishi, and S. Masunaga, "Atmospheric polycyclic aromatic hydrocarbons: size distribution, estimation of their risk and their depositions to the human respiratory tract," Science of the total environment, vol. 340, pp. 71-80, 2005.

[23] J. Schnelle, T. Jänsch, K. Wolf, I. Gebefügi, and A. Kettrup, "Particle size dependent concentrations of polycyclic aromatic hydrocarbons (PAH) in the outdoor air," Chemosphere, vol. 31, pp. 3119-3127, 1995.

[24] S. S. Park, Y. J. Kim, and C. H. Kang, "Polycyclic aromatic hydrocarbons in bulk PM2. 5 and size-segregated aerosol particle samples measured in an urban environment," Environmental monitoring and assessment, vol. 128, pp. 231-240, 2007

[25] O. Amador-Muñoz, R. Villalobos-Pietrini, M. C. AgapitoNadales, Z. Munive-Colín, L. Hernández-Mena, M. Sánchez-Sandoval, S. Gómez-Arroyo, J. L. Bravo-Cabrera, and J. Guzmán-Rincón, "Solvent extracted organic matter and polycyclic aromatic hydrocarbons distributed in sizesegregated airborne particles in a zone of Mexico City: seasonal behavior and human exposure," Atmospheric Environment, vol. 44, pp. 122-130, 2010.

[26] C. Oliveira, N. Martins, J. Tavares, C. Pio, M. Cerqueira, M. Matos, H. Silva, C. Oliveira, and F. Camões, "Size distribution of polycyclic aromatic hydrocarbons in a roadway tunnel in Lisbon, Portugal," Chemosphere, vol. 83, pp. 1588-1596, 2011

[27] J. Zhao, F. Zhang, L. Xu, J. Chen, and Y. Xu, "Spatial and temporal distribution of polycyclic aromatic hydrocarbons (PAHs) in the atmosphere of Xiamen, China," Science of the Total Environment, vol. 409, pp. 5318-5327, 2011.

[28] H. Yu and J. Z. Yu, "Polycyclic aromatic hydrocarbons in urban atmosphere of Guangzhou, China: Size distribution characteristics and size-resolved gas-particle partitioning," Atmospheric environment, vol. 54, pp. 194-200, 2012.

[29] F. Esen, Y. Tasdemir, and N. Vardar, "Atmospheric concentrations of PAHs, their possible sources and gas-toparticle partitioning at a residential site of Bursa, Turkey," Atmospheric Research, vol. 88, pp. 243-255, 2008.

[30] A. Hanedar, K. Alp, B. Kaynak, J. Baek, E. Avsar, and M. T. Odman, "Concentrations and sources of PAHs at three stations in Istanbul, Turkey," Atmospheric Research, vol. 99, pp. 391-399, 2011.

[31] A. Bozlaker, A. Muezzinoglu, and M. Odabasi, "Atmospheric concentrations, dry deposition and air-soil exchange of polycyclic aromatic hydrocarbons (PAHs) in an industrial region in Turkey," Journal of Hazardous Materials, vol. 153, pp. 1093-1102, 2008.

[32] S. Ozcan, "Analytical method optimization and monitoring of priority organic pollutants in Konya city atmosphere," 
Science, Department of Environmental Engineering, Selcuk University, 2007.

[33] M. Odabasi, N. Vardar, A. Sofuoglu, Y. Tasdemir, and T. M. Holsen, "Polycyclic aromatic hydrocarbons (PAHs) in Chicago air," Science of the Total Environment, vol. 227, pp. 57-67, 1999.

[34] F. Esen, "Gas/particle concentration distribution and dry deposition fluxes of polycyclic aromatic hydrocarbons in Bursa atmosphere. Uludag University, the Institute of Natural Science," PhD Thesis, 2006.

[35] S. S. Cindoruk and Y. Tasdemir, "Characterization of gas/particle concentrations and partitioning of polychlorinated biphenyls (PCBs) measured in an urban site of Turkey," Environmental Pollution, vol. 148, pp. 325-333, 2007.

[36] A. Finizio, D. Mackay, T. Bidleman, and T. Harner, "Octanol-air partition coefficient as a predictor of partitioning of semi-volatile organic chemicals to aerosols," Atmospheric Environment, vol. 31, pp. 2289-2296, 1997.

[37] S. Saarikoski, H. Timonen, K. Saarnio, M. Aurela, L. Järvi, P. Keronen, V. Kerminen, and R. Hillamo, "Sources of organic carbon in fine particulate matter in northern European urban air," Atmos. Chem. Phys, vol. 8, pp. 62816295, 2008.

[38] J. Zhou, T. Wang, Y. Huang, T. Mao, and N. Zhong, "Size distribution of polycyclic aromatic hydrocarbons in urban and suburban sites of Beijing, China," Chemosphere, vol. 61, pp. 792-799, 2005.

[39] Air Quality Assessment and Management Regulation (AQAMR),

http://www.mevzuat.gov.tr/Metin.Aspx?MevzuatKod=7.5.1

$2188 \&$ sourceXmlSearch $=\&$ MevzuatIliski $=0$ accessed at $06.16 .201515: 45$

[40] M.-D. Fang, C.-L. Lee, and C.-S. Yu, "Distribution and source recognition of polycyclic aromatic hydrocarbons in the sediments of Hsin-ta Harbour and adjacent coastal areas, Taiwan," Marine pollution bulletin, vol. 46, pp. 941-953, 2003.

[41] B. Pekey, D. Karakaş, and S. Ayberk, "Atmospheric deposition of polycyclic aromatic hydrocarbons to Izmit Bay, Turkey," Chemosphere, vol. 67, pp. 537-547, 2007.

[42] M. C. Lim, G. A. Ayoko, and L. Morawska, "Characterization of elemental and polycyclic aromatic hydrocarbon compositions of urban air in Brisbane," Atmospheric Environment, vol. 39, pp. 463-476, 2005.

[43] M. Akyüz and H. Çabuk, "Particle-associated polycyclic aromatic hydrocarbons in the atmospheric environment of Zonguldak, Turkey," Science of the Total Environment, vol. 405, pp. 62-70, 2008.

[44] P.-J. Tsai, T.-S. Shih, H.-L. Chen, W.-J. Lee, C.-H. Lai, and S.-H. Liou, "Assessing and predicting the exposures of polycyclic aromatic hydrocarbons (PAHs) and their carcinogenic potencies from vehicle engine exhausts to highway toll station workers," Atmospheric Environment, vol. 38, pp. 333-343, 2004.

[45] M. Lodovici, M. Venturini, E. Marini, D. Grechi, and P. Dolara, "Polycyclic aromatic hydrocarbons air levels in Florence, Italy, and their correlation with other air pollutants," Chemosphere, vol. 50, pp. 377-382, 2003.

[46] A. V. Castellano, J. L. Cancio, and P. S. Alemán, "Polycyclic aromatic hydrocarbons in ambient air particles in the city of Las Palmas de Gran Canaria," Environment International, vol. 29, pp. 475-480, 2003.

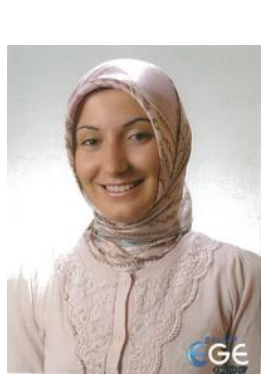

About Author (s):

[High molecular weight PAHs are generally related to particulate matter and therefore it can threaten human health by inhalation. Particle diameters which are lower than 2 micrometers and are 5-6 ring of PAHs; are carcinogenic. It was observed that when particle size decreases, 5-6 ring PAHs concentrations increase.] 